\title{
Cultural Critique and Cultural Orthodoxy in Two Renaissance Plays
}

\author{
Akram Shalghin \\ Jadara University, Jordan
}

Received: 16-07-2014

Accepted: 29-08-2014

Published: 01-10- 2014

doi:10.7575/aiac.ijclts.v.2n.4p.8

URL: http://dx.doi.org/10.7575/aiac.ijclts.v.2n.4p.8

\begin{abstract}
At a time of historically monumental events in England, most notably the transition from feudalism to capitalism and establishing colonies abroad, there had been cultural oscillation between the old mode of life and the new understanding of life. Renaissance literary texts showed signs of criticism of the old tenets but could not register a substantial break up with them. Literary texts were engaged also in the act of colonisation taking place remotely from the English shores, their engagement was subversive at times but contained at others.
\end{abstract}

Keywords: Marlowe, Dr. Faustus, rebellion, Shakespeare, The Tempest, Colonisation, representation

\section{Introduction}

While early forms of criticism were fully engaged in seeing literature as merely from aesthetic perspectives, later trends stepped beyond those latitudes to see literature as a reflection of social life ${ }^{i}$ and later as an inescapably interacting with

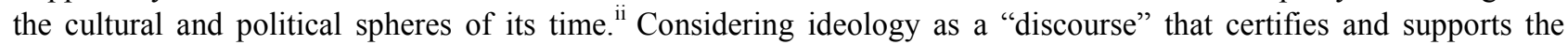
prevailing social and political structure will undoubtedly channel the reading of the literary works to be regarded as types of "discourse" with prospective ideological contents. ${ }^{\text {iii }}$ Renaissance literature has always been a main field of exploration in that respect. Recent studies of Renaissance Literature went further to see it not merely as a monitor or record in relation to society but to study it fundamentally in its ideological effect, to see literature as producing or inducing ideological discourses of the time. Moreover, more recent criticism augmented the cultural and political characteristics of the plays to the extent they would seem on the extreme left or the other way round. ${ }^{\text {iv }}$

Renaissance literary works are often being evaluated, by critics beginning from the early nineties onward, as either defending or opposing in their own historical moments. Consequently they are classified as falling under one of the following possibilities in their relationships to their contemporary authorities and their attendant ideology. Firstly, literary works which stand vigorously to support and reproduce ideology; secondly, those which oppose and challenge ideology through subversive and transgressional implications; and thirdly are those which look as if they are defying ideology but, somehow, are recaptured and entrapped by the very ideology they are defying in an act of 'containment.'

The ideological and cultural tenets that pervaded in the sixteenth, and seventeenth, century were "Christian Humanism" seeking worldly solutions and not supernatural or metaphysical answers to our mysterious questions in, and about, life. The whole social and economical situation was very complicated: it was a transitional period from the "old" Feudalist mode of production in England to capitalism. The ideologies of both Feudalism and Capitalism were confronted. In addition to that, colonisation was set up and encouraged apparently for economical reasons. It was the time English theatre thrived. Religious thinking in the Middle Ages dominated all aspects of man's life and one would rely mainly and ultimately on the church as having the answers to everything related to life. Generally speaking, people were religious and thinking of afterlife and these characteristic overshadowed everything else in their life, thus they were devoted to religion and worshipping. The Renaissance, which appeared originally as a reaction against old forms of thinking and views in life, brought a new way of thinking, a way that could be described as worldly or realistic way of thinking instead of resorting to supernatural elements as the key to understanding life. The Renaissance meant a new way of looking at life, and resolving earthly issues in the light of what is available to man on earth. It meant also bringing up a new kind of thinking that can be identified and called "humanist." This meant a termination to the restrictions put on man's ambitions and attempts to change a situation disregarding what religion and church would robustly instruct. The most significantly substantial differences between the Middle Ages and the Renaissance are those related to art and literature. The latitudes for drama in the medieval were religious ones, preoccupied in just representing and performing biblical and religious stories to the audiences, but with the Renaissance movement literature moved beyond that and its landmarks became worldly and had to do with reason.

\section{Doctor Faustus and Rebellion}

In Christopher Marlowe's Doctor Faustus we are with an aspiring learned scholar scientist. Faustus is first discovered in his study asking himself what exactly he wants; for none of the sciences he has mastered is satisfactory to his enquiring mind: logic, medicine, law, and divinity cannot answer his questions or bring him the world he wants 'a world of profit and delight/ Of power, of honour, of omnipotence' either.(I.i.83-84) ${ }^{\mathrm{v}}$ This dissatisfaction is in itself a rebellion against the confinement within which the human mind is controlled. Let us remind ourselves that the pursuit of knowledge was a major question during the time in which the play was written. Faustus is a true, or perhaps the best, 
representative of his time as a Renaissance figure, in his thirst for knowledge, and in his readiness to go to the farthest point he could in order to achieve what he wants of knowledge and power. He embodies the distinctive characteristics of a true Renaissance man. Faustus is a Renaissance scholar who is shown to fancy the Elizabethan capitalist projects but does not catch either of them: he aspires for the 'search of gold,' he will have the spirits as slaves bringing him what he is pleased to have:

\section{I'll have them fly to India for gold, \\ Ransack the ocean for orient pearl,}

And search all the corners of the new- found world. (I.i.114-6)

His ambitions go far beyond acquiring the power he thought of originally, it is neither the power that would have answered his questions and would have let him know what he could not by what was available to him nor was it the one which would have enabled him to do something that could not, previously, nor was it the power to be put into the service of the common good; his ambition, rather, discloses some kind of capitalist and colonialist rhetoric, that is not exotic to the time in which the play was written, it was the time of transition to capitalism and the time of establishing colonies in the new land, a time of seizing "others"” possessions. In fact, Faustus' discourse changes diametrically after he signed his pact with the devil, he wishes to have the spirits as obedient slaves "As Indian Moors obey their Spanish lords."(I.i.156) The imperial power Faustus fancies is one which would have in all people of the world slaves. The effect is to place Faustus closer to the Colonists with their supremacy over the other people of the world, people who were defeated after they thought of breaking the normal law of supremacy. Faustus will have in the spirits obedient slaves who will bring him "from America the golden fleece."(I.i.164)

Signing away his soul for the duration of twenty four years of complete power makes Faustus repeat Christ's words at the cross 'Consummatum est' as if he is aware that everything is finished, but soon Mephistopheles brings him something "to delight his mind" (I.v.130). Questions to which he thought he would get answers, he finds none, he asks where hell is and is answered that the place where he stands is hell; and not all his desires are achieved such as to have a wife. Faustus's imperialist aspirations are repeated and there are moments in which he surpasses all the colonist figures in the literature of that time, most notably Tamburlaine "I'll be great emperor of the world." Faustus goes on trips where he plays tricks on the Pope's table and conjures up the spirit of Helen of Troy for the entertainment of his friends. After which he realizes his despair becomes quite apparent, and his despair is created out of the contradiction between his original aspiration and his continuous limitation, he "repeatedly moves through a circular pattern, from thinking of joys of heavens, through despairing of ever possessing them, to embracing magical dominion as a blasphemous substitute."vi In the general estimation, Faustus succeeds in challenging the norms; he has owned the power that magic could bring him but his power is very limited if compared with his first ambitious desires; again his success has ended up by the failure to constitute an effective case where the protagonist could continue to hold on to power, rather shortly before the end of his contract he, actually, regretted his first step. By that, there is a negation of what he has dared before, the audience would justifiably think that Faustus is meant to confirm the old belief that man is placed in his position by God where he has no choice or saying, he should willingly accept to remain without any attempt or intention to move; otherwise his punishment will be harsh. As the end of the twenty four years of contraction approaches, Faustus's fear makes him try to repent but even his repentance is unacceptable, the effect of which is a warning against thinking of breaking an ordered life in the first place because there will be no chance to withdraw once one starts: "Let Faustus live in hell a thousand years,/A hundred thousand, and at last be sav'd!" The play ends with a feeling that Faustus's life has ended twenty four years before, his life ended when he signed away his soul, ended in his study where he started to think of rebellion against his God. To end Faustus in this way is to say he has achieved nothing, Faustus wishes his "soul be chang'd into little water drops," and he "will burn" his "books." Faustus's end carries what many would incline to believe as the strategic aim of the play: when he feels the existence of God where Faustus asks him "Look not so fierce on me." Faustus ends up confirming God's authority against which he rebelled in the first place.

The play displays defiant questions and then negates them and concludes, explicitly or otherwise, that these questions were pointless. If Marlowe wanted to free his protagonist from the established norms he did but for a temporary and limited period of time constructed by the need of that particular time after which he was recaptured just to prove that it is inevitable for one to rid from the authorities, religious and otherwise. Dealing with subject Marlowe's play has functions like sedation valid for a short time after which pain must be accepted as inescapable. Marlowe's protagonist's rebellion could be framed as negative and meaningless on the grounds that it ends without a mark to say that the way is effective or when it ends regretting the first step which was taken being an act of seduction. Some would argue that the playwright might have been ironic in closing his play like that whereby the protagonist is being penalised after he has been dissident throughout the play. However, the stages Marlowe's central figure reaches, is whether or not Marlowe was ironic about the old beliefs. One is likely to agree that the question of bringing the Medieval elements of the morality play and challenging them is a subversive act, however this is negated by Faustus's regret and attempts to repent and when he ended up as a damned character for trying to escape them.

The significant point one cannot ignore is to do with the real value of the rebellion. Although Marlowe's rebellious central character is represented, in the main, as reacting to adverse social circumstances and hence his rebellion as partly justified, ultimately, this rebellion is not glorified but rather regarded as leading to tragic consequences, its effect is portrayed as futile. The ending of the protagonist would be taken, simply, as an admonitory lesson where the theatre might have become the (spectacle) scaffold that showed the punishment of the protagonist as an instructive lesson from which the Elizabethan audience would learn. 
Certain aspects would tell us that Faustus is a Renaissance hero but some others would rather tell us that he is a medieval figure. Faustus' desire, and actual step, to try the forbidden knowledge is an act of rebellion against the limitations imposed on human beings by medieval restrictions. He would have proved a purely medieval figure if he would have been like any other character of the time in accepting one's position and not trying to move beyond that. Moreover, Dr. Faustus can be identified as incompatible with the Renaissance also because of the characters it has, the Chorus, the Good Angel and the Evil Angels, Old Man..., let alone the mere fact that Faustus himself knows that his contract ends in 24 years after which he is going to be penalized by supernatural powers. Indeed, shortly before the end of his contract with Lucifer he asks for a very short time so that he would be credited with a chance to repent (see above). Thus the action of dissidence is being negated by his final plead to repent acknowledging that he made a mistake. Thus his Renaissance thirst for knowledge and power was defeated. In fact, Faustus might look a morality play more than being a tragedy.

\section{The Tempest and Colonialism}

Shakespeare was not substantially different from Marlowe in his interaction with the contemporary cultural environment. The time in which he wrote The Tempest witnessed establishing colonies mainly in the New Found World. The play, as has been repeatedly argued, is concerned with the act of colonialism. ${ }^{\text {vii }}$ Its subject-matter and main events confirm specifically its engagement; it presents characters whose relationships to each other signify this association with colonialism. At the beginning of the play, there is a heavy storm destroying a ship with a number of "nobles" on board striving for survival. Miranda, the daughter of the owner of the island, from where she was watching the storm, was moved by what she saw and asked her father to offer them help, but her father disclosed that he orchestrated the storm by some magical powers and capabilities. He did that because of an old retribution, as he explained. Owing to a right he had lost twelve years earlier he wanted to revenge upon the conspirators who were on board, specifically his own brother Antonio who usurped his position. At this point, he reveals his, and his daughter's, story. He tells her that they both were captured and left to die on a raft at sea, and then they miraculously survived and stranded over the very island where they are. Some scholars tend to identify the island as being located in, or having a link to, the New World. ${ }^{\text {vii }}$ Like the contemporary colonialists, Prospero assumed power and control over that island which was not void of people; rather it was inhabited by a few, as the play tells us. This step is an act of colonisation, this is not only because it ignores or neglects the presence of the locals living there but also, and more significantly, because Prospero enslaves them. This act is in line with the English initiative in setting colonies in the New World and their treatment of the indigenous inhabitants.

The overall environment of The Tempest is that which tells of lost rights, conspiracy, vagueness and shifty ambiance that shape both its social as well as it natural spheres. The remote island where the play is set would be associated with the world of primitivism, savagery, filthiness, enslavement, etc. These attributes are combined together to describe this foreign environment. The play starts with plotting; it also has considerable use of the power of magic. Ariel, who lives on the island, possesses magical powers and can do things invisibly, however he is made a permanent subservient to Prospero due to the latter's act of freeing him from a kind of eternal imprisonment. Ariel got stuck in the cleft of a pine tree where Sycorax, a witch, kept him, ever since he is committed to serving Prospero without complaint. The audiences see Ariel as a submissive obedient servant embodying the characteristics of a slave; though he possesses extraordinary power so that he remains invisible to all but Prospero, a role he dutifully performs all the time, Ariel does what he is instructed with by Prospero, but when he once dared to think of asking Prospero about a time limit whereat he can be set free: "Ariel: Is there more toil? Since thou dost give me pains,/Let me remember thee what thou hast promised,/Which is not yet performed me ....... My liberty." (I, ii, 242-45) his request was put down and he was reminded by Prospero of how he was rescued from his imprisonment by Sycorax: "Prospero: Thou liest, malignant thing. Hast thou forgot/ The foul witch Sycorax, who with age and envy/Was grown into a hoop? Hast thou forgot her?" (I, ii, 256-59), a reminder that implies Ariel's indebtedness to Prospero without a reference to time frame or any other comforting words that would offer Ariel a sense of hope that his enslavement is just a phase which is going to come to an end one day. Moreover, Prospero takes his rhetoric further to threaten Ariel: "Prospero: If thou more murmur'st, I will rend an oak/And peg thee in his knotty entrails till/Thou hast howled away twelve winters."(I, ii, 294-96) By that, Prospero's "power" lies not only in fooling his slaves but also in his ability to threaten them. ${ }^{\text {ix }}$ The threat sets Ariel back to his normalized state of accepting enslavement and submissiveness therefore he apologizes and promises to continue executing his duties: "Ariel: Pardon, master./I will be correspondent to command/And do my spriting gently." (I, ii, 295-97). The paradox in Prospero's relationship to Ariel is that he freed the latter from imprisonment not with the will to set an individual free but purely for his own sake to place that individual as his personal slave.

Another figure who lives on the island is Caliban; he is also enslaved by Prospero. But, in the case of Caliban the audiences find a different kind of slave, one who does not easily accept his positioning as a slave to Prospero. Caliban's eccentric behaviour indicates that his response to Prospero springs from intending to be helpful in his own way. His conduct signifies essential cultural ${ }^{\mathrm{x}}$ differences from that of the European Prospero who are used to different norms. Caliban's words would explain that he was welcoming the new comer to the island and demonstrated by deeds his willingness to lend him a hand, but he got stunned as he was enslaved by Prospero. Moreover the new comer turned things upside down for Caliban who, prior to that, enjoyed total freedom and was the king of the place by virtue of being the son of Sycorax, who was the first owner of the island:

“...When thou cam'st first,

Thou strok'st me and made much of me, wouldst give me 
Water with berries in't...

....and then I lov'd thee

And show'd thee all the qualities o' th' isle,

The fresh springs, brine-pits, barren place and fertile.

Curs'd be I that did so!...

For I am all the subjects that you have,

Which first was mine own king; and here you sty me

In this hard rock, whiles you do keep from me

The rest o' th' island." (I.ii.332-334, 336-339, 341-344)

From what Caliban speaks about his case the audiences would, perhaps, know some of his grievances, he is not only deprived of what he previously enjoyed but he is, also, enslaved and mistreated. Additionally, Caliban is never regarded as a normal human being, nor was he placed in a position where he could fall into the category of being an "other;" rather he is described as a "barbarian," "uncultivated" "savage," "a born devil, on whose nature / Nurture can never stick," (IV.i.188-9) He is vilified by virtue of his foreign belonging, behavior and physical appearance. Right from the moment Prospero tells his daughter, Miranda, about the history of the island, he implies to scorn Caliban; he divulges that the island had on it a very ferocious and influential witch called Sycorax who was banished from Algiers for practicing sorcery, she was pregnant and was carried to the island by some sailors where she dominated everything and gave birth to Caliban, she died years before the play started. In depicting Caliban's mother as a witch, the play is already drawing some sort of a barrier between the offspring of a witch and the audiences who had their own understanding of what witchcraft meant and how it was considered. ${ }^{\mathrm{xi}}$ Constructing Caliban as the progeny of a witch is, in one way or another, introducing him as alien and far from being just an "other." Nor was Caliban's name coincidently given by Shakespeare, it is an anagram of Cannibal, a characteristic that European colonizers accused the locals in the Americas with. ${ }^{\text {xii }}$ Caliban was framed within the savage and subhuman categories. He is even given subhuman physical characteristics a "Legg'd like a man! And his fins like arms!" (II.ii.34) "some monster of the isle with four legs" (II.ii.66) As just mentioned, he is described in terms that go beyond considering him a primitive individual, rather he is seen as filthy, smelling, possessing little more than what could render him as an animal. It is legitimate to think that Caliban's character is designed in this way not specifically to show the bias against him by other characters in the play but more drastically to have him as embodying the characteristics of the indigenous as depicted by the offstage European "discoverers." Furthermore, Caliban is reduced to a beast. This is typical for the European colonists (or voyagers) when being encountered with people in the remote places they had been to. It can be seen in the colonialists' description of the indigenous, be that in a reference to their social behavior or more accurately even to their physical "deformity" where some "discoverers" assured seeing creatures whose heads are grown underneath their shoulders or on their chests. This legend can also be seen in some of the literary texts of the time. The Tempest ${ }^{x i i i}$ is not indifferent to that kind of classification of the indigenous as it describes Caliban as being one of the "men/Whose heads stood in their breasts?'(III.iii.45-46) This myth about the barbarity and physical deformation has been later discussed being unsubstantiated in its representation of reality by John Lawson who admitted in his "A New Voyage to Carolina, 1709 "xiv that "We look upon them with Scorn and Disdain, and think them little better than Beasts in Human Shape; though, if well examined, we shall find that for all our Religion and Education we possess more Moral Deformities and Evils than these Savages do, or are acquainted withal."

Unlike that of Ariel's, Caliban's enslavement is marked by resistance due to a number of factors most notably is his feeling that the island belonged to him since his mother Sycorax was the first there and she controlled the island. Additionally, Caliban feels that he is used and abused by Prospero: "This island's mine by Sycorax my mother,/Which thou tak'st from me. When thou cam'st first,/Thou strok'st me and made much of me..." (I.ii.331-34). This is also not to ignore that Caliban received Prospero with the best possible way he could and showed him everything related to the island, places on, and sources in, it. However, to Prospero and his daughter, Caliban is not an equal, he is, as mentioned earlier, barbaric, savage and so on, therefore he should be civilized by certain necessary measures. Their perception of Caliban echoes that of the Europeans when dealing with the natives of the lands. The Europeans considered the indigenous to be void of culture, and that was based not on substantially solid grounds, but on either their own unwillingness to consider and appreciate the culture of the other or they, i.e. the European colonizers, based their attitude towards the "other" on the wrong assumptions that natives did not have deeply rooted cultural identification, rather they were primitive who needed to be enculturated. This is very much reminiscent of what Edward Said demonstrated in his Orientalism on the issue of presentation and representation of the other. The other's cultural identity was to a large degree constructed in the minds of the Europeans disregarding what reality might indicate. ${ }^{\text {xi }}$ In the case of Caliban, certainly he did not have the cultural sophistication as that of the Europeans, but he most likely enjoyed a kind of harmony and self-satisfaction within the spheres of the island where he lived prior to the arrival of Prospero and Miranda. It is possible to argue that Caliban's ways of understanding and perception in life were instinctive and were not shaped by norms and standards in exactly the same way like that of the Europeans, his behaviours are related to what he acquired inside his environment. Thus it is more conceivable for Caliban to have the new comers adapt to his existing way of life, not the other way round. To Caliban's mind, his sexual advances towards Miranda, were prompted by the wish to "people" the "isle with Calibans" (I.ii.351-52) whereas it is, actually, an attempt to rape Miranda. Caliban did not deny what he was accused of regarding the sexual advancement towards Miranda but he spoke up of how he thought. It is possible to read this case as underlying the contrast in each respective perception between Caliban's and that of Prospero; it is to do with who is encroaching on the other! Is it Caliban that intrudes on 
the new comers or they deprive him of his rights! The overall situation would imply a reinforcement of the difference between one who is regarded savage and another who gives himself the right to control and "civilize" that savage. The eyes through which Prospero and his daughter saw Caliban were very suggestive of the ideological legitimations the Europeans used to justify their infringement on, and colonization of, the inhabitants of other geographical lands, precisely the absence of culture and civilization. The endeavor to teach Caliban language is a colonial step; its aim goes far beyond finding the means of communication with him or "civilizing" him, it is actually a step that intends to erase his own identity and re-enculturate him anew. Caliban seemed happy with the way he was originally living previously, it is not similar to that of Prospero's or any other characters in the play; he seemed to have acquired his own natural ways of living in that island, as mentioned earlier. Viewing Caliban as someone who should be educated and civilized does not only mean regarding him as inferior but also giving the self the right to enslave that "lower" "other." However, educating and teaching Caliban proves a difficult mission because of his resistance to give up his own self and to accept what the master, or colonizer, wants. They use force to teach him, and their use of force is made to look legitimate on the grounds of his rejection to educational programmes. ${ }^{\text {xii }}$ However, Caliban learns how to speak the language of the colonizer and his use of it is sometimes "eloquent" and has "poetry" in it to the extent wherewith he proves superiority to the civilized Europeans who express their anger by using very vulgar words ${ }^{\text {xviii }}$ but more often he swears at Prospero. Some critics would read the act of teaching Caliban how to speak the language of Prospero as actually giving him the means to resist, but that is not the case simply because this is not the way by which the colonialists' mind operates when teaching their language to indigenous, rather it has different targets, as mentioned earlier. Caliban's use of the language is self-promulgated as: "You taught me language; and my profit on't/Is, I know how to curse: the red-plague rid you/For learning me your language!(I.ii.364.) Caliban's statement is regarded by Stephen Greenblatt as an achievement "for an instant an absolute if intolerably bitter moral victory." ${ }^{\text {,ix }}$ Despite the attempt to show Caliban resisting enslavement to Prospero, the play does not credit him with the human dignity and eagerness for freedom but it endows him with the characteristic of being only a slave, in particular when meeting Stephano and Trinculo and begging them to be his masters, thus showing him not a resistant to enslavement but resistant to a specific master. He is humiliated further when he is seen apologizing to Prospero for mistaking Stephano and Trinculo "Ay, that I will; and I'll be wise hereafter,/And seek for grace. What a thrice-double ass/Was I to take this drunkard for a god,/And worship this dull fool!" (V.i. 295-98) There is no apparent end to Caliban, the audiences would not be sure whether he would be taken to be exhibited in fairs in Italy as a monster or he would be left alone on the island, thus he remained a savage and unequal to the colonizer, while Prospero remained powerful over the island throughout the play. Prospero is praised by the play and is given enormous powers. The power of magic which Prospero possesses can be regarded as analogical to the advancement the European colonizer had over the natives, so they were capable of embarrassing them, and dominating them. Giving Prospero enormous power and the ability to do things freely is made so merely to reveal him as being capable of solving all the problems of this remotely located island. Prospero is the centre for the action for everyone in the play. He has got supremacy over all of them; this supremacy is an echo of the leading power of the colonized in the New World. In The Tempest, both subversion and containment are clear but Caliban's end would tell more of containment, hence a postcolonial discourse seems unlikely when Caliban cannot see himself outside the role of being a slave. By that, the play is giving significance to the colonialist degrading the colonized. There is no denial, of course, that Caliban's cursing the master and being disobedient to him would endorse the idea of having a space to liberate him, but that remains partial, and the rebellion against the master is negated by showing him as one who cannot be a masterless individual.

\section{Conclusion}

The general lines of the above-discussed plays tend to be similar in their cultural attitudes. Faustus allows its central figure to challenge all established authorities much more than anyone of his age. He overreaches in his challenge to the established social, theological, philosophical horizons of his time but he ends up regretting his deed and begs for even a short time where he could go back in time and be obedient. The Tempest is not different in that pattern whereby it permits a native to rebel against the colonialist Prospero but it shows that not as gratifying the native Caliban and highlighting his human search for freedom, rather the play shows him as even enjoying being a slave; his protest comes against a specific master but not against enslavement. Despite the fact that many tend to see the act of breaking away with the established order and attempting to set up different cultural tunes from the ones known to contemporary audiences, the plays remain captured and cannot go beyond certain limits and cannot cross certain boarders! It is point to celebrate when seeing the plays break up with the establishment, but there is an eventual end to this celebratory point when the curtains close endorsing what had been thought of breaking up with. The plays do fall culturally and ideologically under the third category we discussed at the introductory parts of this paper.

\section{References}

Althusser, L. (1971). 'Ideology and ideological State Apparatus' in Lenin and Philosophy and Other Essays Trans. Ben Brewster. London: New Left Books.

Barber, C. L. (1988). Creating Elizabethan Tragedy, ed., with an Introduction by Richard Wheeler (Chicago \& London

Barroll, J. L., et al., (1975). The Revels History of Drama in English Vol. III 1576 - 1613. ed. Leech, Clifford and Croik, T.W. London: Methuen.

Bennet, T. (1979). Formalism and Marxism. London: Methuen. 
Cartelli, T. (1987). "Prospero in Africa: The Tempest as Colonialist Text and Pretext," in Jean E. Howard, Marion F. O'Connor (eds), Shakespeare Reproduced: The Text in History and Ideology. New York \& London: Methuen.

Brown, P. (1985). “This Thing of Darkness I acknowledge mine': The Tempest and the Discourse of Colonialism,” in Jonathan Dollimore and Alan Sinfield (eds.), Political Shakespeare: New Essays in Cultural Materialism . UK: Manchester Univ. Press.

Chambers, E.K.. (2009). The Elizabethan Stage, Vol. IV. Oxford: The Clarendon Press

Cook, A. J. (1981). The Privileged Playgoer of Shakespeare's London 1576 - 1643. New Jersey: Princeton UP.

Dollimore, J. (1984). Radical Tragedy: Religion, Ideology and Power in the Drama of Shakespeare and His Contemporaries. New York, London, Toronto, Sydney, Tokyo: Harvester

Dollimore, J. and Eagleton, T. (1985). 'Marxist Literary Criticism', Devizes: Sussex Tapes

Edwards, P. (1987). Shakespeare: A Writer's Progress. Oxford: Oxford Univ. Press.

Froude, J.A. (1899). English seamen in the Sixteenth Century: Lectures Delivered at Oxford, Easter Terms.London: Longmans, Green

Gallay, A. (ed.). (1994).Voices of the Old South: Eyewitness Accounts, 1528-1861. USA: Univ. of Georgia Press,

Garber, M.(ed), (1987). Cannibals, Witches, and Divorce: Estranging the Renaissance (Baltimore and London: The Johns Hopkins University Press,).

Geertz, C. ed., (1973). The Interpretation of Cultures. NY: Basic Books, Inc.,

Greenblatt, S. (1991).Marvellous Possessions: Wonder in the New World. Oxford \& NY,

Greenblatt, S. (1992). "Learning to Curse," (1976) rpt. in Stephen J.Greenblatt, Essays in Early Modern Culture. New York and London: Routledge,

Greg, W. W. (ed.). (1968).Christopher Marlowe, Doctor Faustus, (A) Text. Oxford Press

Harbage, A.(1941).Shakespeare's Audience. New York \& London: Columbia University Press

Harrison, W. (1968). Description of England: Folger Documents of Tudor and Stuart Civilisation. Cornell university press

Hattaway, M. (1983)., Elizabethan Popular Theatre. London, Boston, Melbourne and Henley: Routledge and Kegan Paul,

Kermode, F. (ed.), (1958). William Shakespeare, The Tempest Arden edn. London: Methuen

Lawson, J (1709). A New Voyage to Carolina. London

Loomba, A. (2005 ).Colonialism/Postcolonialism. $2^{\text {nd }}$ ed. NY \& London: Routledge.

Mills, S. (1997). Discourse. London \& NY: Routledge

Reeves, E. (2013). "Is it right to see Shakespeare's 'The Tempest' as an anticipation of the dynamics of colonialism?" Electronic Edition https://www.essex.ac.uk/sociology/documents/research/publications/ug_journal/vol9

Said, E. (1978).Orientalism: Western Conceptions of the Orient. Harmondsworth: Penguin Books.

\section{Notes}

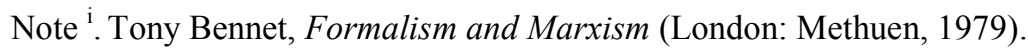

Note ${ }^{i i}$. On the relationship between literature and politics see, for example, Jacques Ranciere, The Politics of Literature (USA: 2011).

Note ${ }^{\text {iii }}$. On exploring 'literature as a discourse,' see, for example, Sara Mills, Discourse. pp. 22-7. Also, see Jonathan Dollimore and Terry Eagleton on 'Marxist Literary Criticism', Devizes: Sussex Tapes, 1985. And, on the ideology and its manifestations in institutions, see Louis Althusser, 'Ideology and ideological State Apparatus' in Lenin and Philosophy and Other Essays Trans. Ben Brewster (London: New Left Books, 1971),

Note ${ }^{\text {iv }}$. See Jonathan Dollimore, Radical Tragedy: Religion, Ideology and Power in the Drama of Shakespeare and His Contemporaries (New York, London, Toronto, Sydney, Tokyo: Harvester, 1984/89).

Note v. Quotations to Dr Faustus are from Christopher Marlowe, Doctor Faustus, (A) Text, ed., W. W. Greg (Oxford: 1968).

Note $^{\text {vi }}$. C. L. Barber, Creating Elizabethan Tragedy, ed., with an Introduction by Richard Wheeler (Chicago \& London: 1988),p.103.

Note vii . See for example, Frank Kermode, (ed.) The Tempest by William Shakespeare, Arden edn. (London: Methuen, 1958). Stephen Greenblatt, "Learning to Curse," (1976) rpt. in Stephen J.Greenblatt, Essays in Early Modern Culture (New York and London: Routledge, 1990/92), Thomas Cartelli, "Prospero in Africa: The Tempest as Colonialist Text and Pretext," in Jean E Howard, Marion F O'Connor (eds), Shakespeare Reproduced: The Text in History and Ideology (New York \& London: Methuen, 1987). 
Note ${ }^{\text {viii }}$. Scholars believe the play is in The New World or Shakespeare might have colonialism in mind when he wrote his play.

Note $^{\text {ix }}$. See Ania Loomba, Colonialism/Postcolonialism. $2^{\text {nd }}$ ed(NY \& London: Routledge, 2005 ), p.185.

Note $^{\mathrm{x}}$. Cultural anthropologists ridicule the old conceptions related to the void of culture at certain people who were not known to Europeans before. On a broader view on the issue, see, for example, Clifford Geertz, ed., The Interpretation of Cultures (NY: Basic Books,Inc., 1973).

Note $^{\text {xi }}$. Witchcraft, in Shakespeare's England, was punishable by burning to death those who were convicted. See, for example, Garry Wills, Witches and Jesuits: Shakespeare's Macbeth (USA: 1996), Reginald Scot, The Discoverie of Witchcraft (USA: Dover Publication, 1989), Marjorie Garber (ed), Cannibals, Witches, and Divorce: Estranging the Renaissance (Baltimore and London: The Johns Hopkins University Press, 1987).

Note ${ }^{\text {xii }}$. Michel de Montaigne one of the European discoverers wrote "Of Cannibals" in 1578 about seeing cannibals somewhere in the Americas he called "Antarctic France" (Brazil).

Note ${ }^{\text {xiii }}$. Similar instances can be seen in Othello (I.iii.166-170).

Note ${ }^{\text {xiv. }}$ See John Lawson, A New Voyage to Carolina, 1709 (London: 1709) (Electronic Edition:

http://docsouth.unc.edu/nc/lawson/lawson.html).

Note $^{\mathrm{xv}}$. See Allan Gallay (ed), Voices of the Old South: Eyewitness Accounts, 1528-1861(USA: Univ.of Georgia Press, 1994),p.40.

Note $^{\text {xvi }}$. See Edward Said, Orientalism: Western Conceptions of the Orient (Harmondsworth: Penguin Books, 1978).

Note $^{\text {xvii }}$. See Paul Brown, “This Thing of Darkness I acknowledge mine': The Tempest and the Discourse of Colonialism," in Jonathan Dollimore and Alan Sinfield (eds.), Political Shakespeare: New Essays in Cultural Materialism (UK: Manchester Univ. Press, 1985), p.61.

Note ${ }^{\text {xviii }}$. See Philip Edwards, Shakespeare: A Writer's Progress (Oxford: Oxford Univ. Press, 1987), p. 175. See also Emma Reeves, "Is it right to see Shakespeare's 'The Tempest' as an anticipation of the dynamics of colonialism?" https://www.essex.ac.uk/sociology/documents/research/publications/ug_journal/vo19/2013sc396_emmareeves.pdf (p.6.) (accessed 06.07.2014).

Note $^{\text {xix }}$. Stephen Greenblatt, Learning to Curse: Essays in Early Modern Culture (New York and London: Routledge,1992). p. 25. 